\title{
Pemrosesan dan Penyimpanan Informasi pada Otak Anak dalam Belajar: Short Term and Long Term Memory
}

\author{
Ririn Musdalifah \\ Universitas Islam Negeri Sunan Kalijaga \\ Email: ririnmusdalifah66443@gmail.com
}

\begin{abstract}
Neuroscience theory is an education system that studies the nervous system. Learning theory which prioritizes processing that occurs in the brain nerves, in neuroscience itself studies neuroanatomy and neurophysiology, both of which need to be studied to improve the quality of learning that is very pleasant. Point as a goal, neuroscience learning to understand the purpose of education will increase, if you do not understand neuroscience of learning, the goals to be achieved will not rise. This paper intends to explain the processing and storing of information in short-term memory and long-term memory of early childhood brain in learning.
\end{abstract}

Keywords: Theory of Neuroscience, Information Processing, Short and Long Term Memory Storage

\begin{abstract}
ABSTRAK
Teori neuroscience merupakan sistem pendidikan yang mempelajari tentang sistem saraf. Teori belajar yang lebih mengutamakan pada pemrosesan yang terjadi pada saraf otak, dalam ilmu saraf itu sendiri mempelajari neuroanatomi dan neurofisiologi, keduanya perlu dipelajari untuk meningkatkan kualitas pembelajaran yang sangat menyenangkan. Titik sebagai tujuan, ilmu saraf belajar untuk memahami tujuan pendidikan akan meningkat, kalau tidak mengerti ilmu saraf pembelajaran, tujuan yang ingin dicapai tidak akan naik. Tulisan ini bermaksud menjelaskan tentang
\end{abstract}


pemrosesan dan penyimpanan informasi dalam memori jangka pendek dan memori jangka panjang otak anak usia dini di dalam belajar.

Kata kunci: Teori Neurosains, Pemrosesan Informasi, Penyimpanan Memori Jangka Pendek dan Panjang.

\section{PENDAHULUAN}

\section{Latar Belakang}

Memori atau daya ingat merupakan sesuatu yang sangat penting bagi manusia karena merupakan kekuatan jiwa manusia untuk menerima, menyimpan, memproses dan mereproduksi kesan-kesan, pengertianpengertian atau tanggapan-tanggapan. Memori manusia dapat diolah secara sadar (concius processing) dan secara otomatis. Pengolahan secara sadar biasanya menimbulkan tindakan-tindakan baru sedangkan pengolahan secara otomatis biasanya menghasilkan tindakan reflek atau secara tiba-tiba dengan waktu yang pendek. Dimana pada masa anak-anak merupakan salah satu masa dalam rentang kehidupan manusia yang pasti dilalui oleh semua manusia di dunia ini.

Pada masa usia dini, terjadi banyak sekali proses penanaman nilai kehidupan yang pertama kali. Pada masa ini pulalah suatu masa yang relatif panjang bagi anak-anak untuk belajar tentang segala hal. Pada masa inilah anak-anak mengalami proses perkembangan dalam berbagai macam hal, seperti perkembangan fisik, perkembangan kognitif, perkembangan mental, perkembangan sosial, perkembangan emosional, maupun perkembangan moral. ${ }^{1}$ Anak memiliki banyak potensi pada masing-masing bentuk perkembangan tersebut. Agar dapat mengoptimalkan potensi pada tiap-tiap

\footnotetext{
${ }^{1}$ Hanafie Das, S. W. (2013). Implementasi Brain Based Teaching pada Tanan Kanak-kanak di Kota Parepare (Telaah Kritis Pendidikan Agama Islam bagi Anak Usia Dini) (Doctoral dissertation, Universitas Islam Negeri Alauddin Makassar).
} 
perkembangan anak tersebut, maka anak harus difasilitasi dalam wadah yang tepat, yakni pendidikan yang tepat. ${ }^{2}$

Pendidikan yang tepat bagi anak agak memicu perkembanga otak yang sehat dan efektif. Kajian neurosains sangat erat kaitannya dengan pendidikan karena pendidikan dapat mempengaruhi perkembangan neurosains dan begitu juga sebaliknya. Tujuan yang dapat diharapkan dalam penerapan teori Neurosains dalam pendidikan tersebut ialah agar peserta didik mampu mengelolah penyimpanan informasi dalam memori jangka pendek dan jangka panjang. Memori ini sangat membantu perkembangan kemampuan peserta didik terutama dalam peningkatan kualitas akademik.

\section{Permasalahan}

Diskursus pemrosesan informasi berbasis otak sangat penting dikaji dalam konteks belajar. Hal tersebut yang menjadi permasalahan dalam tulisan ini adalah:

1. Bagaimana hakikat neurosains dalam hubungannya dengan belajar?

2. Bagaimana cara kerja short term memory dan long term memory?

3. Bagaimana relasi short term memory dan long term memory dengan aktivitas belajar?

\section{METODE PENELITIAN}

Penelitian ini library research yaitu penelitian yang dilakukan di ruang perpustakaan untuk menghimpun dan menganalisis data yang bersumber dari perpustakaan, baik berupa buku-buku, periodikal-periodikal, seperti majalah-majalah ilmiah yang diterbitkan secara berkala, kisah-kisah sejarah, dokumen-dokumen dan materi perpustakaan lainnya, yang dapat dijadikan sumber rujukan untuk menyusun suatu laporan ilmiah. ${ }^{3}$ Sumber data yakni dari literatur terkait dengan kajian yang dibahas, baik dalam

${ }^{2}$ Halik, Abdul. "Paradigm of Islamic Education in the Future: The Integration of Islamic Boarding School and Favorite School." Information Management and Business Review 8.4 (2016): 24-32.

${ }^{3}$ Abdurrahmat Fathoni, Metodologi Penelitian dan teknik Penyusunan Skripsi (Jakarta: PT. Rineka Cipta, 2006), h. 96. 
bentuk buku referensi, hasil penelitian, maupun jurnal ilmiah. Teknik pengumpulan data yakni studi dokumen dari literatur dan rederensi yang terbaru dan relevan. teknik analisis adalah Aktifitas analisis data model ini antara lain, reduksi data (data reduction), display data dan gambaran konklusi atau verifikasi (conclusion drawing/verification). ${ }^{4}$ Data yang diperoleh dilakukan analisis konten (content analysis) terhadap tema agar ditemukan jawaban (solusi) yang tepat.

\section{PEMBAHASAN}

\section{Hakikat Neurosains}

Masa anak-anak merupakan salah satu masa dalam rentang kehidupan manusia yang pasti dilalui oleh semua manusia di dunia ini. Pada masa inilah terjadi banyak sekali proses penanaman nilai kehidupan terutama yang tersimpan pada otak seseorang. ${ }^{5}$ Pada masa ini pulalah, orang tua mulai mendidik dan memberikan pendidikan terbaik untuk anaknya karena harapan dari para orangtua yang selalu menginginkan anak-anaknya nanti dapat menjadi seseorang yang berguna dan dapat sukses di masa mendatang. Oleh sebab itu, akan dideskripsikan seorang anak dalam pemrosesan dan penyimpanan informasi dalam memori jangka pendek dan memori jangka panjang di otak seorang anak.

Neurosains secara etimologi adalah ilmu neural (neural science) yang mempelajari sistim syaraf, terutama mempelajari neuron atau sel syaraf dengan pendekatan multidisipliner. ${ }^{6}$ Kajian tentang sel syaraf sudah berkembang dengan cepat, sehingga menjadi salah satu disiplin ilmu terbaru sekarang ini. Secara terminologi, neurosains merupakan bidang ilmu yang

\footnotetext{
${ }^{4}$ Sugiyono, Metode Penelitian Pendidikan Pendekatan Kuantitatif, kualitatif, dan $R \& D$ (Bandung: Alfabeta, 2010).

${ }^{5}$ Das, S. W. H. (2018, July). The Character Education of Early Childhood: BrainBased Teaching Approach. In 2018 3rd International Conference on Education, Sports, Arts and Management Engineering (ICESAME 2018). Atlantis Press.

${ }^{6}$ Taufik Pasiak, Tuhan Dalam Otak Manusia, Mewujudkan Kesehatan Spiritual Berdasarkan Neurosains (Bandung: Mizan, 2012), 132.
} 
mengkhususkan pada studi saintifik terhadap sistim syaraf. Dengan dasar ini, neorosains juga disebut sebagai ilmu yang mempelajari otak dan seluruh fungsi-fungsi syaraf belakang. ${ }^{7}$

Tujuan utama dari ilmu ini adalah mempelajari dasar-dasar biologis dari setiap perilaku. Artinya, tugas utama dari neurosains adalah menjelaskan perilaku manusia dari sudut pandang aktivitas yang terjadi di dalam otaknya. Penelitian mutakhir di bidang neurosains menemukan sejumlah bukti hubungan tidak terpisahkan antara otak dan perilaku (karakter) manusia. Otak merupakan pusat aplikasi manusia yang dapat memberikan intruksi kepada seluruh elemen, dipengaruhi oleh stimulus yang didapatkan dari luar, sejumlah pengetahuan yang tersimpan dalam memori, respon terhadap stimulus yang ada. Hal tersebut mereflekasikan sebagai sebuah prilaku seseorang melalui kematangan dalam mengelola syaraf dengan berbagai pendekatan.

Melalui instrumen Positron Emission Tomography (PET) diketahui bahwa terdapat enam sistem otak (brain system) yang secara terpadu meregulasi semua perilaku manusia. Keenam sistem otak tersebut adalah cortex prefrontalis, sistem limbik, gyros cingulatus, ganglia basalis, lobus temporalis, dan cerebellum. Keenam sistem otak tersebut mempunyai peranan penting dalam pengaturan kognisi, afeksi, dan psikomotorik, termasuk IQ, EQ, dan SQ. ${ }^{8}$ Pemisahan jasmani, ruhani dan akal akan berimplikasi pada pengembangan ketiganya (IQ, EQ dan SQ) ${ }^{9}$ yang secara otomatis melanggengkan ketidakseimbangan pada ranah kognisi, afektif dan psikomotorik dalam pembelajaran. ${ }^{10}$ Bukti ilmiah ini memberi inspirasi

${ }^{7}$ Wikipedia, "Neurosains," Http://Id.Wikipedia.Org/Wiki/Neurosains, 2019.

${ }^{8}$ Suyadi, "Model Pendidikan Karakter Dalam Konteks Neurosains", Proceeding Seminar Nasional," Yogyakarta: Prodi PGMI Fakultas Tarbiyah UIN Sunan Kalijaga (2012): 12.

${ }^{9}$ Halik, A. (2013). Implementasi Manajemen Pembelajaran Pendidikan Agama Islam Berbasis Intelectual, Emotional, dan Spiritual Quotient (IESQ)(Telaah di Universitas Muhammadiyah Parepare) (Doctoral dissertation, Universitas Islam Negeri Alauddin Makassar).

${ }^{10}$ Adi W. Gunawan, Genius Learning Strategy, Petunjuk Praktis Menerapkan Accelerated Learning (Jakarta: Gramedia, 2013), 258. 
bahwa pendidikan karakter tidak ubahnya dengan mengembangkan potensi otak. Semua sistem dalam otak bekerja secara padu untuk membangun sikap dan perilaku manusia.

Oleh sebab itu, meregulasi kinerja otak secara normal akan menghasilkan fungsi optimal sehingga perilaku dapat dikontrol secara sadar dengan melibatkan dimensi emosional dan spiritual. Dengan demikian, pendidikan karakter dapat dijelaskan dalam mekanisme kerja otak pada tingkat molekuler, khususnya enam sistem di atas. Atas dasar inilah neurosains yang disebut ilmu yang menghubungkan antara otak dan pikiran (brain-mind connection) atau jiwa dan badan, termasuk hati dan akal. Contoh di atas menunjukkan bahwa dunia pendidikan selama ini masih memisahkan (untuk tidak mengatakan mengalami konflik paradigma) antara otak-pikiran, jiwa-badan, dan akal-hati.

Taufik Pasiak menyatakan bahwa, otak hanya bisa didefinisikan jika dikaitkan dengan pikiran. Tanpa pengertian ini, otak tidak memberikan makna apa-apa selain sebuah benda yang tidak berbeda dengan benda-benda biologis lainnya. Demikian pula dengan jiwa-badan dan akal-hati. Semuanya tidak dapat dipisahkan satu sama lain dengan otak. Semua entitas itu (pikiran, jiwa, dan hati/rasa) bersumber (software) pada otak manusia. Di sinilah neuroanatomi dan neurofisiologi menjadi bermakna sebagaimana dimaksudkan sejak pertama kalinya ilmu itu ditemukan.

\section{Memori Jangka Pendek dan Memori Jangka Panjang}

Memori adalah kemampuan mental untuk menyimpan dan mengingat kembali sensasi, kesan dan ide-ide. Terdapat beberapa proses yang terjadi sebelum suatu informasi tersimpan sebagai suatu ingatan, yaitu 1. Penyandian informasi (encoding)

Penyandian informasi merupakan proses memasukkan informasi dengan mengubah informasi tersebut menjadi sinyal yang dapat diproses oleh otak.

\section{Penyimpanan (storage)}

Penyimpanan merupakan proses mempertahankan informasi dalam suatu jangka waktu. Layaknya sebuah komputer, informasi yang diterima 
dapat disimpan dalam jangka waktu sementara atau dalam jangka waktu yang lebih lama.

3. Mengingat kembali (retrieval)

Mengingat kembali merupakan proses mengakses informasi yang telah disimpan untuk digunakan kembali.

Proses penyimpanan data ini dapat berupa memori sensorik, memori jangka pendek, dan memori jangka panjang. Memori jangka pendek, yang disebut juga sebagai memori primer atau working memory menyimpan informasi dalam jangka waktu sementara dengan kapasitas terbatas $7 \pm 2$ item dalam satu waktu. Memori jangka pendek menyimpan informasi selama 15-30 detik dan akan hilang bila tidak dilakukan pengulangan.

\section{Memori Jangka Pendek (Short Term Memory/STM)}

Pemrosesan dan Penyimpanan Informasi dalam Memori Jangka Pendek Seorang Anak Saat kita berpikir tentang memori, kita sering membayangkan suatu tempat penyimpanan luas yang berisi informasi dan pengetahuan. Jenis memori semacam itu umumnya disebut memori jangka panjang (LTM; long-term memory), dan merupakan suatu aspek dari memori kita. Meskipun STM memiliki kapasitas yang jauh lebih kecil dibandingkan LTM, STM memiliki peranan penting dalam dalam pemrosesan memori. Suatu karakteristik lain pada STM adalah kapasitas penyimpanan yang terbatas diimbangi oleh kapasitas pemrosesan yang terbatas, dan bukan hanya itu, terdapat pula pertukaran (trade-off) konstan antara kapasitas penyimpanan dan kemampuan pemrosesan. ${ }^{11}$

Teknik Brown-Peterson, sebuah teknik penelitian yang dilakukan oleh Lloyd Peterson, Margaret Intons-Peterson pada tahun 1959 dan J. A. Brown, 1958, mendemostrasikan bahwa kapasitas kita untuk menyimpan informasi dalam area penyimpanan sementara bersifat sangat terbatas dan rentan terhadap memudarnya informasi dengan cepat, jikalau kita tidak memiliki kesempatan mengulang (rehearse) informasi tersebut. Artinya proses penyimpanan ini berlangsung dalam jangka waktu yang singkat dan

\footnotetext{
${ }^{11}$ Robert L, Solso, Otto H. Maclin, M. Kimberly Maclin, Psikologi Kognitif (Jakarta: Erlangga, 2007), h. 164.
} 
sering kali muncul gejolak-gejolak dalam menemukan identitas atau jati diri mereka sendiri.

Sejumlah fitur-fitur istemewa pada STM dan bagaimana fitur-fitur tersebut selaras dengan pemahaman kita tentang pemrosesan dan teori-teori memori. Berdasarkan hasil penelitian suami istri Peterson (dan penelitianpenelitian lainnya), sejumlah gagasan yang mendukung keberadaan dua penyimpanan memori dapat dirangkum sebagai berikut:

1. Pengamatan sehari-hari menunjukkan bahwa sejumlah hal diingat selama sesaat sedangkan hal-hal lainnya diingat dalam jangka waktu yang lama.

2. Eksperimen-eksperimen psikologis menunjukkan bahwa pengambilan sejumlah informasi dalam memori adalah karakteristik kinerja memori jangka pendek, sedangkan pengambilan sejumlah informasi yang lain adalah karakteristik kinerja memori jangka panjang, misalnya terkait data awal dan akhir (primacy and recency data).

3. Studi-studi fisiologis menunjukkan bahwa kinerja memori jangka pendek dapat mengalami hambatan, sedangkan kinerja memori jangka panjang tampak tetap stabil. ${ }^{12}$

\section{Penyandian Informasi STM}

Penyandian Informasi yang tersimpan dalam memori jangka pendek adalah 21 informasi auditorik, visual dan semantik."Olak melakukan ketiga macam penyandian tersebut. Penjelasan ketiga macam penyandian tersebut sebagai berikut:

1. Penyandian auditorik

Dukungan terhadap penyandian anditorik berasal dari sehuah eksperimen yang dilakukan Conrad pada tahun 1963. Conrad menemukan bahwa kekeliruan dalam memori jangka pendek bersumber dari kekeliruan auditorik. Dalam eksperimennya, dia menayangkan huruf-huruf yang bunyinya mirip ('B' dan V) dan berdasarkan huruf tersebut, dia menyusun rangkaian-rangkaian huruf yang tiap rangkaiannya disajikan kepada

\footnotetext{
${ }^{12}$ Robert L, Solso, Otto H. Maclin, M. Kimberly Maclin, Psikologi Kognitif..., h. 166.
} 
partisipan secara auditorik dan visual. Sehingga diasumsikan bahwa memori yang terlibat dalam pemrosesan informasi bersifat akustik.

2. Penyandian visual

Eksperimen yang mendukung gagasan ini adalah eksperimen pencocokan kata yang dilakukan Posner. Dalam eksperimen tersebut, peneliti menyajikan huruf-huruf berpasangan dengan tiga model. Kemudian partisipan diminta untuk menunjukkan apakah huruf yang ditampilkan tersebut adalah huruf yang sama. Huruf-huruf disajikan satu demi satu dengan jeda waktu yang bervariasi. Peneliti mengasumsikan bahwapartisipan memerlukan waktu lebih lama untuk melakukan penyandian secara visual karena perbedaan ketiga model huruf tersebut.

3. Penyandian semantilk

Penyandian semantik merupakan sandi yang herhubungan dengan makna. Dalam seuah eksperimen Wickens melakukan uji coha pada seorang partisipan untuk mengingat sebuah daftar yang berisi dengan nama nama buah. Pada uji coba pertama partisipan tersebut dapat mengingat $90 \%$ dari daftar nama buah yang telah diberikan. Kemudian pada uji coba kedua partisipan diberikan daftar kedua yang berisi nama-nama buah lagi, maka diasumsikan partisipan akan mengalami kesulitan untuk mengingat kedua daftar tadi karena adanya penimbunan makna, sehingga menyehahkan berkurangnya kemampuan mengingat.

\section{Penyimpanan Informasi STM}

Fakta yang paling jelas tentang ingatan jangka pendek adalah kapasitasnya yang sangat terbatas. Rata-rata batasnya adalah tujuh butir lehih arau kurang dua $(7+2)$ Sebagian orang dapat menyimpan sedikitnya lima butir, on lan dapat menyimpan sebanyak sembilan butir. Mungkin aneh melihat angka yang tepat untuk mencakup semua orang sementara jelas bahwa individu sangat berbeda dalam kemampuan memorinya. Tetapi perbedaan tersebut sebagian besarnya disebabkan karena memori jangka pendek. Untuk ingatan jangka pendek, sebagian besar orang dewasa mempunyai kapasitas 72. Kekonstanan ini telah dikerahui sejak awal psikologi eksperimental. 
Herman Ebbinghaus, yang memulai penelitian eksperimental tentang memori pada tahun 1885, melaporkan hasil yang membuktikan hahwa hatas yang dimilikinya sendiri tujuh butir. Sekitar 70 tahun kemudian, Goerge Miller (1956) juga menemukan kekonstanan yang dinamakan "angka tujuh yang ajaib". Batas ini juga ditemukan oleh kultur yang bukan barat. ${ }^{13}$ Ahli psikologi menentukan angka ini dengan menunjukkan kepada subjek berbagai urutan butir-butir yang tidak berhubungan (angka, huruf atau kata) dan kemudian meminta subjek untuk mengingat butir ersebut secara berurutan. Butir-butir itu dipresentasikan secara cepat dan subjek tidak memiliki waktu untuk mengubahnya menjadi informasi yang disimpan dalam memori jangka panjang Dengan demikian, jumlah butir yang diingat hanya mencerminkan 23 kapasitas penyimpanan memori jangka pendek. ${ }^{14}$ Kapasitas STM sebenarnyna hanya dapat memuat 7 kapasitas ingatan 2) dan berdurasi sekitar 15-30 detik. Dengan kata lain, seorang dewasa mampu mengingat 5-9 kapasitas ingatan selama kurang lebih 15 hingga 30 detik. $^{15}$

\section{Peranan STM}

Memori jangka pendek berperan penting dalam proses berpikir. Dalam melakukan suatu pemecahan masalah, memori jangka pendek digunakan untuk menyimpan sebagian dari masalah sembari mengakses informasi dari memori jangka panjang yang relevan dengan masalah tersebut sehingga dapat menjadi suatu informasi yang lengkap dalam memecahkan masalah. Peranan pemecahan masalah di antaranya meliputi persoalan aritmatika, analogi geometri dan pemahaman bahasa dalam percakapan maupun teks. Derajat aktivasi memori jangka pendek diketahui berpengaruh terhadap kecepatan proses kognitif dalam menunjang proses belajar anak. Selain berperan dalam pemecahan masalah dan proses kognitif, memori jangka pendek juga merupakan 'way-station' ke memori

\footnotetext{
${ }^{13}$ Atkinson, Pengantar Psikologi, Jilid I, Edisi 11, Diterjemahkan Oleh Widjaya Kusuma (Batam: Interaksara, 1993), h. 485.

${ }^{14}$ Atkinson, Pengantar Psikologi, Jilid I, Edisi 11, Diterjemahkan Oleh Widjaya Kusuma. 2008).

${ }^{15}$ Deasy Harianti, Metode Jitu Meningkatkan Daya Ingat (Jakarta Selatan: Batam,
} 
jangka panjang. Artinya, informasi terlebih dahulu berada di memori jangka pendek sebelum disandikan ke memori jangka panjang.

\section{Pengukuran STM}

Memori jangka pendek sering diukur dalam rentang memori (memory span) yaitu penyajian tunggal beberapa item berupa angka, huruf, atau simbol yang dapat diulang kembali tepat sesudah penyajian. Tes ini umumnya dimasukkan ke dalam tes intelegensi. Tes dengan angka disebut tes Digit Span. Tes ini merupakan bagian dari skala WISC-IV yang termasuk dalam Working Memory Index (WMI). Tes Digit Span terdiri dari dua sub tes: Digits Forward dan Digits Backward. Pada tes Digits Forward, suatu deretan angka diucapkan oleh penguji dengan kecepatan satu angka per detik, kemudian anak diminta untuk mengulangi deretan angka tersebut sebagaimana yang diucapkan oleh penguji. Apabila anak menjawab benar dalam dua percobaan dari suatu seri, tes dilanjutkan ke seri berikutnya dengan satu angka lebih banyak hingga maksimal sembilan angka. Pada tes Digits Backward, dilakukan dengan cara semua, tetapi anak harus mengucapkan kembali deretan angka tersebut dalam urutan terbalik sampai maksimal delapan deret angka. Sebagai contoh, jika penguji mengucapkan: 5-9-8-4-7, maka anak menirukan: 7-4-8-9-5. ${ }^{16}$

\section{Pengambilan Informasi dari STM}

Era modern pemrosesan informasi sangat dipengaruhi oleh sebuah teknik eksperimental yang dikembangkan oleh Saul Sternberg (1966, 1967, 1969), Teknik ini melibatkan sebuah tugas pemindaian serial (serial scenning task) yang di dalamnya partisipan mendapatkan stimuli berupa serangkaian item, misalnya angka, dengan jeda 1,2 detik setiap item. Diasumsikan bahwa item-item tersebut disimpan dalam STM partisipan. Setelah partisipan menghapalkan daftar, ia menekan sebuah tombol untuk memunculkan sebuah angka yang ada (atau tidak ada) dalam daftar yang telah dilihat sebelumnya. Tugas partisipan adalah membandingkan angka tersebut dengan daftar yang telah diingatnya dan menjawab apakah angka tersebut memang ada di daftar atau tidak. Setiap tugas berisi daftar yang

\footnotetext{
${ }^{16}$ Deasy Harianti, Metode Jitu Meningkatkan Daya Ingat.
} 
berbeda. Para peneliti mengubah-ubah ukuran daftar sesuai kapasitasSTM, yakni dari satu hingga enam angka. Pada dasarnya, tugas ini (yang kini disebut tugas Sternberg atau Sternberg task) mengharuskan partisipan mencari angka-angka dalam satu daftar untuk menemukan jawaban yang tepat. Pencarian semacam ini dapat berhenti dengan sendirinya (selfterminating) saat partisipan telah menemukan angka tersebut dan memberikan jawaban. ${ }^{17}$

\section{Memori Jangka Panjang (Long Term Memory/LTM)}

Memori jangka panjang adalah tempat pembelajar menyimpan pengetahuan dan keyakinan umum mereka tentang dunia, hal yang telah mereka pelajaridi sekolah dan ingatan mereka tentang berhagai peristiwa dalam kehidupan pribadi mereka. ${ }^{18}$ Memori jangka panjang merupakan tempat menyimpan ingatan berbagai hal dan memiliki sifat saling menghubungkan. Memori jangka panjang adalah memori yang sudah terkodifikasi dan tersimpan secara menyeluruh dalam otak. Memori jangka panjang bertindak sebagai hard drive yang menjadi tempat penyimpanan pengalaman yang telah lalu di daerah kulit luar otak (Cerebral Cortex). Manusia dapat memiliki ingatan yang kuat karena kemampuan memori jangka panjangnya bagus. Mereka dapat memindahkan informasi dari memori jangka pendek mengkaitkan informasi harn dengan pengetahuan awal yang telah dipelajari.

\section{Penyandian Informasi dari LTM (Penyandian makna)}

Untuk material verbal, representasi memoi jangka panjang yang dominan bukan auditorik ataupun visual, tetapi didasarkan pada makna butir. Penyandian butir menurut maknanya terjadi jika buti itu adalah kata terisolasi, tetapi lebih jelas jika butir itu adalah kalimat. Beberapa menit setelah mendengar suatu kalimat, sebagian hesar dari pemhaca akan mengingat atau mengenali makna kalimat. Penyandian makna selalu terjadi

\footnotetext{
${ }^{17}$ Deasy Harianti, Metode Jitu Meningkatkan Daya Ingat ..., h. 175.
}

${ }^{18}$ Jeanne Ellis Ormrod, Sixth Edition Education Psychology Developing Learners Diterjemahkan Oleh Wahyu Indianti, Eva Septiana, Airin Y Saleh, Puji Lestari Dengan Judul Edisi Keenam Psikologi Pendidikan Membantu Siswa Tumbuh Dan Berkembang (Jakarta: Erlangga, 2008), h. 282. 
dalam situasi meoi sehari-hari. Walaupun makna mungki merupakan cara dominan untuk merepresentasikan material verbal dalam memori jangka panjang, kita kadang-kadang menyandikan aspek lain pula. Memori jangka panjang memiliki sandi preferensinya untuk material verbal.

\section{Penyimpanan Informasi dari LTM}

Informasi yang tersimpan dalam memori jangka panjang disimpan dalam berbagai kode. Pengkodean tersebut dapat berupa kode verbal, imajeri ataupun semantik. Menurut Lots Loftus dalam kegagalan pengambilan tampaknya bukan satu-satunya kegagalan pengingatan. ${ }^{19}$ Fakta bahwa beberapa pengingatan disebabkan oleh kegagalan pengambilan tidak berlaku pada semua kegagalan pengingatan tampaknya kecil kemungkinan bahwa segala sesuatu yang pernah kita pelajari masih terdapat di dalam memori menunggu isyarat pengambilan yang benar. Sebagian informasi hampir dipastikan hilang dari penyimpanannya

\section{Pengambilan Informasi dari LTM}

Pengambilan informasi dari memori jangka panjang dapat dilakukan dengan melakukan kode. Kode tersebut dapat berupa kode visual, verbal, semantik ataupun imajeri. Banyak kasus melupakan memori jangka panjang berasal dari hilangnya akses ke informasi dari pada hilangnya informasi itu sendiri. Artinya, daya ingat yang buruk seringkali mencerminkan kegagalan pengambilan ketimbang kegagalan penyimpanan. Mencoba mengambil (mengingat) dari memori jangka panjang dapat disamakan dengan mencari sehuah buku di perpustakaan hesar Kegagalan menemukan buk idak berarti buku itu tidak ada disana, anda mungkin mencari di tempat yang salah, atai mungkin mencari di tempat yang salah, dan dengan demikian tidak dapat diakses Dari penjelasan di atas maka memori dibedakan menjadi dua berdasarkan tingkatannya, yakni memori jangka pendek dan memori jangka panjang. Memori jangka pendek hanya memiliki kapaitas antara 15-30 detik saja. Sedangkan memori jangka panjang adalah memori yang sudah tersimpan dan terkodifikasi secara menyeluruh di otak. Penelitian ini lebih

\footnotetext{
${ }^{19}$ Atkinson, Pengantar Psikologi, Jilid I, Edisi 11, Diterjemahkan Oleh Widjaya Kusuma, (Batam: Interaksara, 1993), h. 503.
} 
terfokus pada memori jangka panjang, karena memori jangka panjang merupakan tempat pembelajar menyimpan pengetahuan dan keyakinannya tentang segala hal yang telah mereka pelajari.

\section{Faktor-Faktor Yang Mempengaruhi Belajar}

1. Faktor Internal

Faktor internal adalah faktor-faktor yang berasal dari dalam diri individu dan dapat memengaruhi hasil belajar individu. Factor-faktor internal meliputi:

a) Faktor Fisiologis

1) Keadaan tonus jasmani

Kondisi fisik yang sehat dan bugar memberikan pengaruh positif terhadap kegiatan belajar individu. Sebaliknya, kondisi fisik yang lemah atau sakit akan menghambat tercapainya hasil belajar yang maksimal.

2) Keadaan fungsi jasmani/fisiologis

Peran fungsi fisiologis pada tubuh manusia sangat memengaruhi hasil belajar, terutama pancaindra. Pancaindra yang berfungsi dengan baik akan mempermudah aktivitas belajar dengan baik pula. Dengan menyediakan sarana belajar yang memenuhi persyaratan, memeriksakan funsi mata dan telinga secara priodik, mengongsumsi makanan bergizi, dan lain sebagainya.

b) Faktor Psikologis

1) Kecerdasan/intelegensi peserta didik

Kecerdasan diartikan sebagai kemampuan psikofisik dalam mereaksi rangsangan atau menyesuaikan diri dengan lingkungan melalui cara yang tepat. Dengan demikian, kecerdasan bukan hanya berkaitan dengan kualitas otak saja, tetapi juga organ-organ tubuh yang lain. Namun, bila dikaitkan dengan kecerdasan, tentunya otak merupakan organ yang penting dibandingkan organ yang lain, karena fungsi otak itu 
sendiri sebagai pengendali tertinggi (executive control) dari seluruh aktivitas manusia.

2) Motivasi

Motivasilah yang mendorong peserta didik ingin melakukan kegiatan belajar. Para ahli psikologi mendefiniskan motivasi sebagai proses di dalam diri individu yang aktif, mendorong, memberikan arah, dan menjaga perilaku setiap saat.

3) Minat

Secara sederhana, minat (interst) berarti kecenderunga dan kegairahan yang tinggi atau keinginan yang besar terhadap sesuatu. Menurut Reber (Syeh, 2003), minat bukanlah istilah yang popular dalam psikologi disebabkan ketergantungan terhadap berbagai faktor internal lainnya, seperti pemusatan perhatian, keingintahuan, motivasi, dan kebutuhan.

4) Sikap

Sikap adalah gejala internal yang berdimensi efektif berupa kecendrungan untuk mereaksi atau merespond dengan cara yang relative tetap terhadap objek, orang, peristiwa, dan sebagaimana, baik secara positif maupun negatif. Sikap peserta didik dalam belajar dapat dipengaruhi oleh perasaan senang atau tidak senang pada performan guru, pelajaran, atau lingkungan sekitarnya.

5) Bakat

Secara umum, bakat (aptitude) didefinisikan sebagai kemampuan potensial yang dimiliki seseorang untuk mencapai keberhasilan pada masa yang akan datang. Dengan demikian bakat adalah kemampuan seseorang yang menjadi salah satu komponen yang diperlukan dalam proses belajar seseorang.

2. Faktor Eksternal

a) Lingkungan sosial

1) Lingkungan sosial masyarakat 
Kondisi lingkungan masyarakart tempat tinggal peserta didik akan memengaruhi belajar peserta didik. Lingkungan peserta didik yang kumuh, banyak pengangguran dan anak terlantar juga dapat memengaruhi aktivitas belajar peserta didik, paling tidak peserta didik kesulitan ketika memerlukan teman belajar diskusi, atau menjamin alat-alat belajar yang kebetulan belum dimilikinya.

2) Lingkungan sosial keluarga

Lingkungan ini sangat memengaruhi kegiatan belajar . ketegangan keluarga, sifat-sifat orangtua, demografi keluarga (letak rumah), pengelolaan keluarga, semuanya dapat memberika dampak terhadap aktivitas belajar peserta didik. Hubungan antara anggota keluarga, orangtua, anak, kakak, atau adik yang harmonis dan akan membantu peserta didik melakukan aktivitas belajar dengan baik.

3) Lingkungan sosial sekolah seperti guru, adriministrasi, dan teman-teman sekelas dapat memengaruhi proses belajar seorang peserta didik .hubungan yang harmonis antara ketiganya dapat menjadi motivasi bagi peserta didik untuk belajar lebih baik di sekolah.

b) Lingkungan nonsosial

1) Lingkungan alamiah Seperti kondisi udara yang segar, tidak panas dan tidak dingin, sinar yang tidak terlalu silau/kuat, atau tidak terlalu lemah/gelap. Suasana yang sejuk dan tenang. Lingkungan alamiah tersebut merupakan faktor-faktor yang dapat memengaruhi aktivitas belajar peserta didik. Sebaliknya, bila kondisi lingkungan alam tidak mendukung, proses belajar peserta didik akan terhambat.

2) Faktor instrumental

Yaitu perangkat belajar yang dapat digolongkan dua macam. Pertama, hardware (perangkat keras), seperti gedung sekolah, alat-alat belajar, fasilitas belajar, lapangan olahraga, dan lain 
sebagainya. Kedua, software (perangkat lunak), E-Learning, kurikulum sekolah, peraturan-peraturan sekolah, buku panduan, silabus, dan lain sebagainya.

\section{KESIMPULAN}

Neurosains memiliki banyak cabang ilmu tentang syaraf. Neuroanatomi (struktur otak) dan neurofisiologi (fungsi otak) perlu dipertimbangkan para pendidik untuk digunakan sebagai dasar keberhasilan mematangkan keberhasilan masa depan anak di mulai dari proses pengolahan otak di masa golden ages. Dimana memiliki dua pembagian ingatan yaitu memori jangka pendek yang memiliki kapasitas yang cukup terbatas dapat menampung sekitar tujuh item tidak lebih dari 20 atau 30 detik setiap kali dan cepat membusuk sedangkan memori jangka panjang memiliki kapasitas yang lebih yang mampu menyimpan informasi dalam jumlah tak terbatas. Kedua memori tersebut dimiliki oleh setiap anak dan ingatan dalam belajarnya dipengaruhi oleh berbagai faktor dalam kehidupan sehari-hari baik lingkungan keluarga dan lingkungan sosial.

\section{DAFTAR PUSTAKA}

Adi W. Gunawan. Genius Learning Strategy, Petunjuk Praktis Menerapkan Accelerated Learning. Jakarta: Gramedia, 2013.

Atkinson. Pengantar Psikologi, Jilid I, Edisi 11, Diterjemahkan Oleh Widjaya Kusuma. Batam: Interaksara, 1993.

Das, S. W. H. (2018, July). The Character Education of Early Childhood: Brain-Based Teaching Approach. In 2018 3rd International Conference on Education, Sports, Arts and Management Engineering (ICESAME 2018). Atlantis Press. 
Deasy Harianti. Metode Jitu Meningkatkan Daya Ingat. Jakarta Selatan: Batam, 2008.

Fathoni, Abdurrahmat. Metodologi Penelitian dan teknik Penyusunan Skripsi. Jakarta: PT. Rineka Cipta, 2006.

Halik, A. (2013). Implementasi Manajemen Pembelajaran Pendidikan Agama Islam Berbasis Intelectual, Emotional, dan Spiritual Quotient (IESQ)(Telaah di Universitas Muhammadiyah Parepare) (Doctoral dissertation, Universitas Islam Negeri Alauddin Makassar)

Halik, Abdul. "Paradigm of Islamic Education in the Future: The Integration of Islamic Boarding School and Favorite School." Information Management and Business Review 8.4 (2016): 24-32.

Hanafie Das, S. W. (2013). Implementasi Brain Based Teaching pada Tanan Kanak-kanak di Kota Parepare (Telaah Kritis Pendidikan Agama Islam bagi Anak Usia Dini)(Doctoral dissertation, Universitas Islam Negeri Alauddin Makassar)

Jeanne Ellis Ormrod. Sixth Edition Education Psychology Developing Learners Diterjemahkan Oleh Wahyu Indianti, Eva Septiana, Airin Y Saleh, Puji Lestari Dengan Judul Edisi Keenam Psikologi Pendidikan Membantu Siswa Tumbuh Dan Berkembang. Jakarta: Erlangga, 2008.

Robert L, Solso, Otto H. Maclin, M. Kimberly Maclin. Psikologi Kognitif. Jakarta: Erlangga, 2007.

Sugiyono. Metode Penelitian Pendidikan Pendekatan Kuantitatif, kualitatif, dan $R$ \& D. Bandung: Alfabeta, 2010. 
Suyadi. "Model Pendidikan Karakter Dalam Konteks Neurosains", Proceeding Seminar Nasional." Yogyakarta: Prodi PGMI Fakultas Tarbiyah UIN Sunan Kalijaga (2012).

Taufik Pasiak. Tuhan Dalam Otak Manusia, Mewujudkan Kesehatan Spiritual Berdasarkan Neurosains. Bandung: Mizan, 2012.

Wikipedia. "Neurosains.” Http://Id.Wikipedia.Org/Wiki/Neurosains, 2019. 